\title{
Comunicación y memoria: el fotoperiodismo como testigo de la violencia. Fuentes documentales de la Guerra Civil Española (1936-1939)
}

\author{
Alicia PARras PARras \\ Universidad Complutense de Madrid \\ aparras@ucm.es \\ Julia R. CELA \\ Universidad Complutense de Madrid \\ jurodrig@ucm.es
}

Enviado: 30 de junio de 2014

Recibido: 28 de octubre de 2014

\begin{abstract}
Resumen
Durante la Guerra Civil Española (1936-1939), el fotoperiodismo conoce su edad de oro gracias a míticos fotógrafos extranjeros, como Robert Capa o Gerda Taro, pero también gracias a los fotógrafos españoles que debido a su compromiso con la causa republicana, vieron su trabajo relegado al ostracismo. Su memoria sólo comenzó a ser reivindicada y valorada tras la muerte de Franco y la llegada de la democracia a nuestro país. De este modo, veremos frente a frente las nuevas fuentes documentales del fotoperiodismo extranjero y el trabajo de los fotoperiodistas españoles, quienes fueron los grandes desconocidos, aunque ellos también inmortalizaron las principales batallas, y a las víctimas civiles del conflicto.
\end{abstract}

Palabras clave: Fotoperiodismo; Guerra Civil Española (1936-1939); Agustí Centelles; fotógrafo ; Alfonso; Hermanos Mayo; Brigadas Internacionales.

\section{Communication and Memory: photojournalism as a witness of violence. Documentary sources of the Spanish Civil War (1936-1939)}

\begin{abstract}
Throughout the Spanish Civil war (1936-1939) photojournalism meets its known as Golden Age, specially because of mythical photographers such as Robert Capa or Gerda Taro. However, it is also owing to the work of spanish photographers whose work was concealed by the dictatorship because of their truly commitment with the republican cause. Their memory, their work, started to be appreciate only after Franco's death and only once the democracy finally arrived to our country. Thus, we will see face-to-face the new documentary sources of information about foreign photojurnalism versus the spanish big-unknown photographers, they were who inmortalized the main battles and the inocent victims of the war.
\end{abstract}

Key words: Photojournalism; Spanish Civil war (1936-1939); Agustí Centelles; Alfonso photographer; Hermanos Mayo; International Brigades. 


\section{Referencia normalizada:}

Parras Parras, A. y R. Cela, J. (2014). Comunicación y memoria: el fotoperiodismo como testigo de la violencia. Fuentes documentales de la Guerra Civil Española (1936-1939). Historia y Comunicación Social. Vol. 19. Páginas 113-131.

Sumario: 1. Introducción. 2. Fotógrafos españoles en acción: Centelles, Alfonso y los Hermanos Mayo. 2.1. Agustí Centelles (1909-1985). 2.2. Alfonso Sánchez Portela (1902-1990). 2.3. Los Hermanos Mayo. 3. Las fotografías camino del exilio: La maleta mexicana. 4. Fuentes para el estudio del fotoperiodismo durante la Guerra Civil Española. 4.1. El Archivo fotográfico de la Delegación de prensa y propaganda de Madrid. 4.2. Fondo fotográfico de la Guerra Civil de la Biblioteca Nacional de España (BNE). $4.3 \mathrm{El}$ Archivo fotográfico de la AABI (Asociación de Amigos de las Brigadas Internacionales). 5. Conclusiones. 6. Referencias bibliográficas.

\section{Introducción}

La Guerra Civil Española supuso un antes y un después en la historia del fotoperiodismo mundial. Entre los factores a los cuales ello pudo deberse encontramos: el auge y época dorada de las grandes publicaciones como la revista Life en Estados Unidos o $V u$ en Francia, que contaron con fotógrafos hoy míticos, de la talla de Robert Capa o Gerda Taro; las mejoras técnicas que permitieron el uso de cámaras de fotos mucho más ligeras y compactas como Leica o Rolleiflex; o el sentimiento de empatía e identificación de los fotógrafos con el pueblo español, víctima del conflicto. A lo largo de este artículo, veremos las novedades documentales que han salido a la luz, de estos míticos fotógrafos extranjeros que al huir del nazismo se toparon con el fascismo español y lo combatieron con una cámara de fotos; y, por otro lado, de forma más pormenorizada veremos el trabajo realizado por fotógrafos españoles como Alfonso (hijo), que retrató las trincheras y el conflicto, pero también el lado más cotidiano de la guerra en diversos pueblos y ciudades de España; o de Agustí Centelles, que estuvo presente en el Frente de Aragón y fue colaborador del Comisariado de Propaganda de la Generalitat de Cataluña; así como del colectivo de fotógrafos que ellos mismos se denominaron los Hermanos Mayo. Todos estos fotógrafos sufrieron en primera persona las represalias y el trauma de la guerra: mientras que el primero vio como el Régimen Franquista le retiraba su carnet de fotoperiodista, los demás, vivieron y desarrollaron su carrera profesional en el exilio, e incluso algunos de ellos fueron confinados en distintos campos de concentración al sur de Francia. Y todos, se convirtieron en testigos de la violencia ejercida sobre los civiles, y sus imágenes en la voz de las víctimas.

Por último, también daremos cuenta de algunas fuentes para el estudio del fotoperiodismo durante la Guerra Civil, como el Archivo Rojo, o el Archivo recopilado por la AABI (Asociación de Amigos de las Brigadas Internacionales) que nos permiten poder contemplar las trincheras y los distintos frentes de batalla, así como la vida cotidiana de la España en guerra. 


\section{Fotógrafos españoles en acción: Centelles, Alfonso y los Hermanos Mayo}

Aunque los grandes fotoperiodistas como Robert Capa, Gerda Taro o David Seymour Chim forjaron el inicio de su propia leyenda personal y profesional con las fotografías que tomaron en la Guerra Civil Española, también hubo fotógrafos españoles que trabajaron en la contienda. Entre ellos destacaríamos la labor realizada por Agustí Centelles, Alfonso, los Hermanos Mayo ${ }^{1}$, o ANTIFAFOT ${ }^{2}$.

Y aún hoy en día, nos preguntamos ¿Por qué sus trabajos son menos conocidos que los de los fotógrafos extranjeros? En primer lugar, podemos deducir que ello puede deberse a que, al ser fotógrafos comprometidos de alguna manera con la causa republicana, su trabajo se silenció durante la dictadura franquista y solo desde hace algunos años este comienza a reivindicarse y recuperarse; y también porque durante el conflicto vivieron la escasez de materiales para desempeñar su trabajo (rollos de film, etc.) y de las propias publicaciones que también quedaron desabastecidas.

En este artículo daremos debida cuenta del trabajo y trayectoria vital de estos fotógrafos españoles, porque son un perfecto ejemplo de fotoperiodistas que vivieron el trauma de las represalias de la guerra y la posguerra, como veremos a continuación.

\subsection{Agustí Centelles (1909-1985)}

Centelles nace en Valencia en el año 1909, aunque cuando apenas cuenta con un año de edad su familia se traslada a Barcelona. La fotografía de Centelles desempeñó un papel importantísimo durante la Guerra Civil y se podría afirmar que fue uno de los primeros fotoperiodistas españoles; tanto es así, que incluso es comparado en múltiples ocasiones con Robert Capa llegándose a decir de él que "es el Robert Capa español". La realidad es que en sus fotos de la Guerra Civil encontramos un cierto parecido con aquellas que realizaba Capa, debido a que Centelles también fotografiaba con una cámara Leica y desde muy cerca. Incluso llegaron a coincidir en ocasiones en el mismo escenario de la contienda. De hecho, en una instantánea tomada por Capa en la batalla de Teruel en 1938 publicada en el número 24 de la revista Life, ese mismo año se veía a un fotógrafo corriendo hacia la escena y, cuando ampliamos dicha imagen podemos comprobar que este resulta ser, Agustí Centelles (ELVIRA, 2011). Pero también Capa aparece en una foto de Centelles del 28 de octubre de 1938 durante la despedida de las Brigadas Internacionales en Barcelona. Y también ambos fotógrafos coincidieron una vez más en el campo de concentración de Bram, donde Centelles estuvo internado (Oliva y Mariñosa, 2012).

Según el editor Joaquín D. Gasca la diferencia entre ambos fotoperiodistas a la hora de enfocar su objetivo, opina Gasca, es que Centelles está fotografiando su guerra y en este sentido es muy próximo a los personajes que muestra y es cómplice de las imágenes con las que sabe captar el sentimiento y el dramatismo que envuelve la guerra. En cambio, considera que Capa es muy frío o muy cínico, y consigue la fuerza en sus imágenes gracias a su dominio de la técnica y la plástica (EFE,2012) 
En cualquier caso, Agustí Centelles comenzó a trabajar en el mundo de la fotografía en la técnica del retrato en el año 1924, como aprendiz de Ramón Baños. Más tarde, en 1927 trabajaría de ayudante de Josep Badosa con quien aprendió y se interesó por el fotoperiodismo, que sería su especialidad y verdadera vocación, lo cual se demuestra cuando comienza a colaborar en importantes publicaciones de la época, como: El Día Gráfico, La Vanguardia o Última hora y para las agencias internacionales como Havas o Associated Press. Una vez que estalla la Guerra Civil, Centelles no duda en hacer de la cámara de fotos su mejor arma, y así lo vemos cuando en el año 1937 es destinado a la Unidad de Servicios Fotográficos del Ejército del Este y al año siguiente, en 1938, se encarga de la organización del archivo fotográfico del Ejército de Cataluña, por lo que su compromiso con el bando republicano fue incondicional (Ferré Panisello, 2012:92).

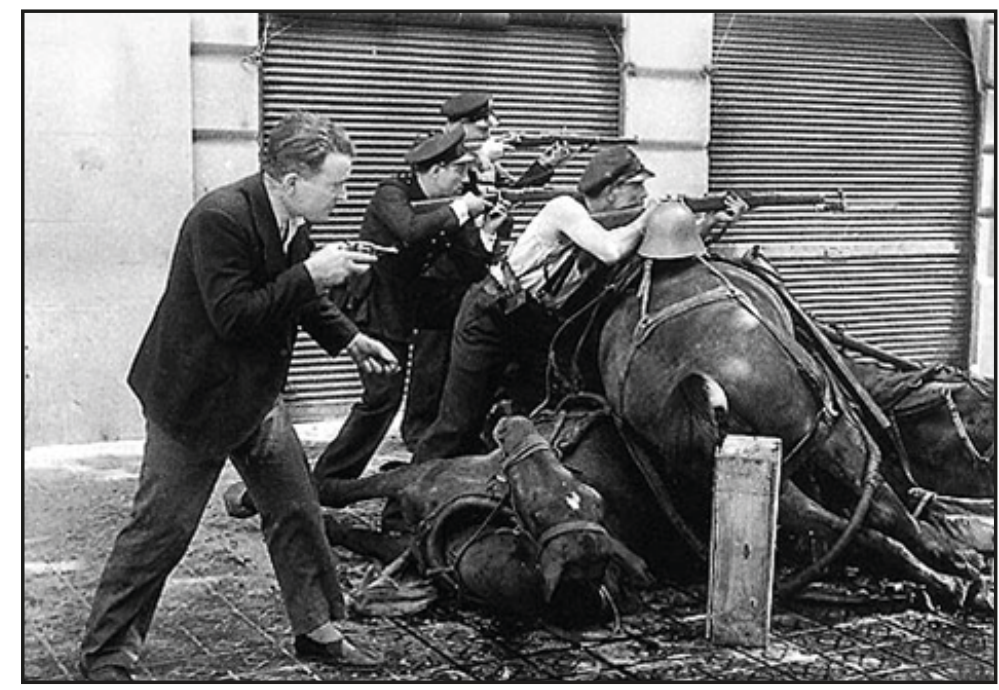

Fig. 1. Fotografía de Agustí Centelles. 19 de julio de 1936

Esta fotografía tan conocida de Centelles y publicada en Newsweek, Paris-Soir o La Vanguardia, es en realidad un montaje que el mismo reconoció. Fechada el 19 de julio de 1936, apenas un día después de que comenzase la guerra, cuando el fotógrafo llegó al lugar de los hechos, la acción ya había sucedido pero pidió a los protagonistas, que aún estaban allí, que simulasen lo vivido. Por otra parte, fotografió unos caballos muertos en la calle y la suma de ambas fotos es la imagen que ha llegado hasta nosotros (Trallero, 2009).

Así, Centelles es testigo por un lado, de las batallas, como las de Belchite o Teruel, y por otro, del sufrimiento de las víctimas civiles inocentes; y como esas víctimas que retrata él también vive la derrota republicana y cómo no, el exilio. En febrero de 1939, cruza a pie a Francia portando 4.000 clichés aproximadamente en una maleta a sabiendas de que si los deja en España serán destruidos por manos franquistas 
(Moreno y Bauluz, 2011). Poco tiempo después de cruzar la frontera, Centelles es internado en el campo de concentración de Bram (Francia) donde aprovecha para fotografiar la situación de los exiliados españoles entre los que se encuentra. En cualquier caso, Centelles fue un fotógrafo y un hombre comprometido, por lo que también una vez en Francia se une a la Resistencia francesa. En 1946 decide volver a España, a Cataluña, donde se entrega y es juzgado por las autoridades franquistas obteniendo la libertad condicional a cambio de no volver a ejercer el fotoperiodismo. De este modo, Centelles es en realidad condenado al silencio y al olvido, aunque jamás abandona la fotografía dedicándose el resto de su vida al ámbito publicitario e industrial (Moreno y Bauluz, 2011).

Finalmente, una vez fallecido Franco, su labor y contribución a la fotografía española comienza a ser reconocida, y un año antes de su fallecimiento se le otorga el Premio Nacional de Fotografía en 1984 (El País, 1984). Solo un año después, Agustí Centelles fallece en Barcelona. En la actualidad son sus hijos Sergi y Octavi quienes se encargan de mantener viva su memoria.

\subsection{Alfonso Sánchez Portela (1902-1990)}

Alfonso es algo más que un nombre en la historia de la fotografía española, es toda una dinastía de fotógrafos en nuestro país, que da comienzo con el padre del Alfonso al que nos vamos a referir, Alfonso Sánchez García (1880-1953). Su hijo Alfonso Sánchez Portela (o Alfonsito) aprendió la técnica y el estilo fotográfico de su padre y con tan solo dieciocho años emprende su carrera como fotógrafo publicando fotografías de la ciudad de Madrid de tipo costumbrista en El Heraldo. También fue un gran retratista de personalidades de la época, como Federico García Lorca o Rafael Alberti, entre otros muchos. En el año 1921 cubre para la prensa de la época, la guerra de Marruecos y fotografía al líder de las tribus rifeñas (que se sublevaron contra las autoridades coloniales españolas y francesas) Abd El Krim y el desembarco de Alhucemas. Seis años más tarde, en 1927 viajará hasta Senegal para documentar la vida en el continente africano. Y en 1931 será testigo privilegiado del alzamiento de la II República española (Custodio, 1977).

Sin embargo, fue en la Guerra Civil Española donde desarrollará su más importante labor como fotoperiodista, especialmente cubriendo la lucha en el frente de Madrid y la batalla de Teruel (donde casi muere de frío), pero también estuvo en Somosierra, en el Puerto de los Leones, Navacerrada, Guadalajara, Andújar, Medellín, Castuera, Toledo... (Custodio, 1977:40). Lo más interesante es que supo captar no solo los frentes de batalla y los combates desde las trincheras, sino también la cotidianeidad de la guerra, la vida diaria de la población civil, pese a la situación de violencia física y psíquica que se ejerce sobre la población, (especialmente en el Madrid cercado), demostrando así la supervivencia del ser humano ante situaciones límites, y como la vida se impone en su curso cotidiano, pese a todo. Una vez finalizada la contienda, el nuevo régimen franquista continuará aplicando la violencia, represaliando a todos aquellos que se encontraban en el bando de los vencidos. 


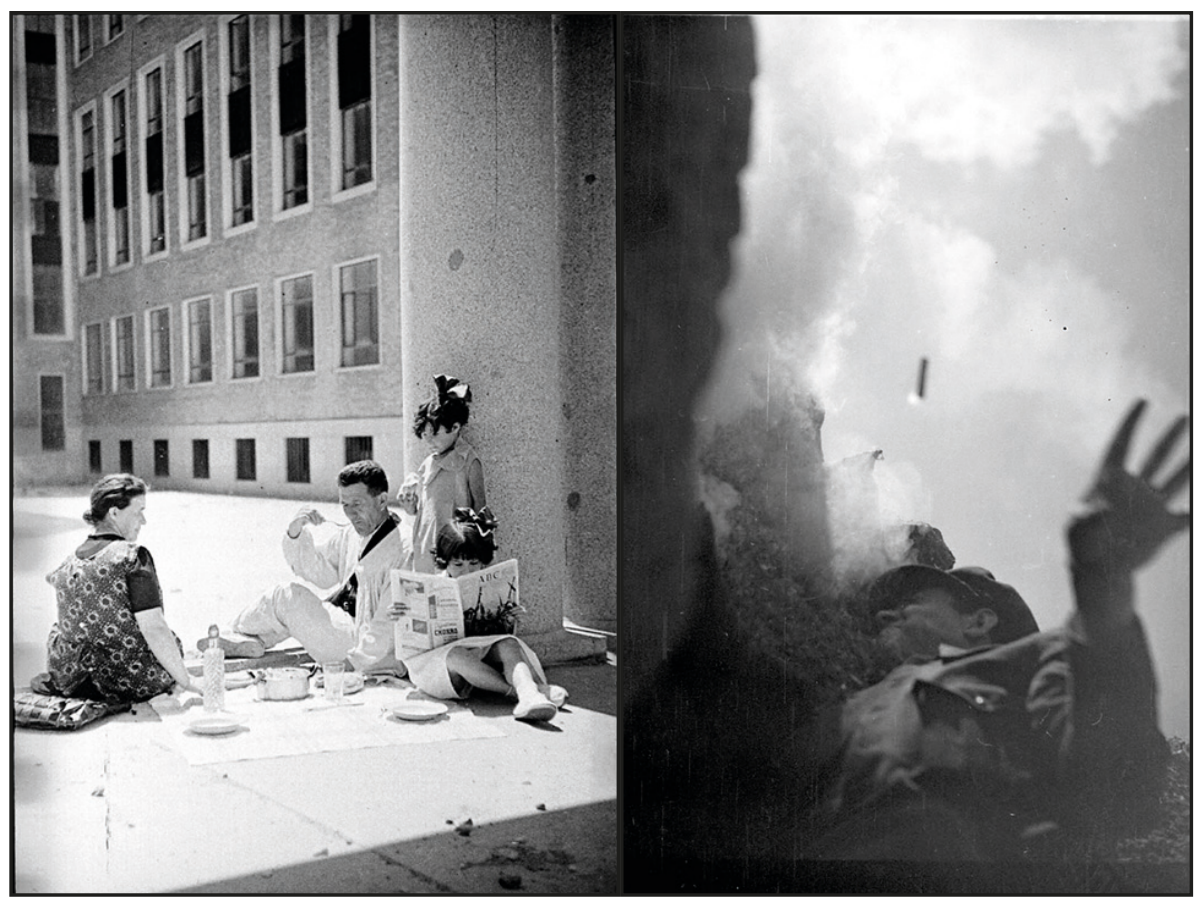

Fig. 2. Fotografía de la izquierda: La normalidad de Madrid (a pesar de la guerra). S.R. Terrazas de los cafés, puestos callejeros, de los mercados. La comida del albañil (Julio, 1936).

Fig. 3. Fotografía de la derecha: Alfonso: Guerra Civil. Estudio Fotográfico "Alfonso". AGA.

Así de este modo, en 1939 a Alfonso se le retira el carnet de periodista, que no le sería devuelto hasta 1952: El 8 de febrero de 1952, se me volvió a dar el título de redactor gráfico de Prensa, del que ya no volvi a hacer uso. Mis hermanos y yo nos hemos consagrado a nuestro estudio Museo y a la Agencia Gráfica Informativa (Custodio, 1977:41). Este es el caso al igual que Centelles de otro gran fotoperiodista que abandona la profesión dedicándose, eso sí, a lo que más aman la fotografía, pero desde una posición silenciosa que no incomodara a las autoridades franquistas.

\subsection{Los Hermanos Mayo}

Si hubiese que definir a los Hermanos Mayo en pocas palabras estás serían organización, compromiso y motivación. Tras una historia que parece sacada de un film y que es poco conocida en España, debido al silencio que sobre ellos cayó tras la llegada de la dictadura franquista, se encuentra el trabajo de esta cooperativa de fotógrafos formada por los hermanos Souza (Francisco, Julio y Cándido), los Del Castillo (Faustino y Pablo), Manuel Gaitán y Landelino Wensel (De Souza Mayo, N.D:10). Los creadores de esta saga fueron los Hermanos Souza (llamándose así la cooperativa embrión de la futura Hermanos Mayo). El hermano mayor Francisco, tras la muerte 
del padre, quedó como responsable de la familia y se convierte en piloto de aviación, donde aprenderá el oficio de fotógrafo tras tomar un curso de fotografía aérea. También fue uno de los primeros españoles en utilizar una cámara Leica de $35 \mathrm{~mm}$ (Hernández Ríos y Tolosa Sánchez, 2011). Sin embargo, y tras participar en la sublevación contra Miguel Primo de Rivera fue enviado al Sáhara español a cumplir un año de condena. A su regreso, se encuentra con que la II República había sido proclamada y, poco después en el año 1934, los tres hermanos fundan por fin la cooperativa Hermanos Souza (Hernández Ríos y Tolosa Sánchez, 2011). Tal fue el éxito que alcanzan, que pronto deben ampliar la familia, y así contratan al fotoperiodista Manuel Gaitán y, poco después, a Faustino del Castillo, discípulo de José María Díaz Casariego. Y siempre bajo la misma premisa del trabajo organizado en equipo, sin personalismos, sin nadie que resalte sobre los demás, esto hace posible que mientras Francisco, Julio, Manuel y Faustino se encargan de fotografiar los acontecimientos del momento, Cándido sea el encargado de las tareas de laboratorio.

Sin embargo, ¿cuál fue el acontecimiento que hizo que este grupo de fotógrafos adoptase el nombre por el que son hoy conocidos? Hay muchas versiones, algunas de ellas contradictorias, pero parece ser que tomaron su nombre de la festividad del primero de mayo, festividad internacional del trabajo. En esa fecha a principios de los años treinta, según Francisco de Souza Mayo, hijo de Cándido, realizaron una serie de fotografías que dieron la vuelta al mundo y dieron reconocimiento nacional a la agencia acerca de la brutal represión de una manifestación por parte de la Guardia Civil en Madrid. En concreto, señala una imagen en la que un Guardia Civil decapita a un hombre mientras esperaba para entrar en la Iglesia del Cristo de Medinaceli. Así, las autoridades se lanzaron a confiscar esos controvertidos negativos, y para evitar que posibles represalias recayesen sobre los Souza, el equipo hasta entonces llamado Hermanos Souza pasó a llamarse Hermanos Mayo (De Souza Mayo, N.D:8). No obstante, el mismo Julio Souza Fernández, señala en un reportaje realizado por Ana María Pascual y publicado en Interviú el 15 de febrero de 2010: Hicimos fotos de la revolución de los mineros asturianos en 1934 y la policía registraba nuestra casa en busca de los negativos. Decidimos cambiar de nombre y de residencia. No recuerdo bien los motivos para llamarnos Mayo, puede ser por la fecha primero de mayo. Y según Faustino el nombre se debía a que todo el mundo se refería a la famosa foto de la represión en Madrid como las fotos de mayo y Mayo pasó a ser su sobrenombre hasta que, tras la revolución de Asturias en 1934 y el compromiso de Francisco con los obreros asturianos (llegó a unirse a la causa junto con La Pasionaria) decidió cambiar oficialmente el nombre a Foto Mayo para protegerse a él mismo y a su familia (Mraz, 2000:1).

En cualquier caso, pronto llegaría la Guerra Civil, y tres de los citados fotógrafos: Francisco, Julio y Faustino acudirían al frente, mientras Cándido quedaría encargado de la agencia, que sería itinerante debido al acoso franquista. Tomaron fotos simultáneamente en Guadalajara, Brunete, Carabanchel, El Jarama, Talavera de la Reina, y Teruel (De Souza Mayo, N.D:8-11). La temática de sus imágenes varía pero suponen una excelente documentación tanto de edificios asolados por la guerra como de las 
víctimas y sus familiares e incluso evacuaciones que se convirtieron en elemento propagandístico para el bando republicano. El propio Francisco fue nombrado director de Fotografía del Estado Mayor del Ejército y de Fotografía del Servicio de Inteligencia Militar.

Con el final del conflicto también llegaría el exilio a Francia. Los Hermanos Mayo fueron confinados en distintos campos de concentración (Francisco estuvo en el de Saint-Ciprien y Faustino y Cándido en el castillo de Collioure) aunque no perdieron el contacto epistolar entre ellos. Esto fue posible gracias a que Francisco había ostentado un cargo en el Estado Mayor que le permitió contactar con Fernando Gamboa, diplomático mexicano que le ayudó a reunirse con Faustino y Cándido, y a salir de Francia rumbo a Veracruz, México, en el barco Sinaia el 26 de mayo de 1939 (Hernández Ríos y Tolosa Sánchez, 2011)³. Una vez en México, volvieron a trabajar como fotógrafos e introdujeron la cámara Leica en el fotoperiodismo mexicano jugando un papel comparable, -en palabras de John Mraz-, al que jugaron Erich Salomon, Alfred Eisenstaedt y Robert Capa en Estados Unidos ${ }^{4}$.

Sin embargo, todavía hoy nos preguntamos ¿qué ocurrió con su archivo? Sobre el cual nos encontramos con varias versiones. Según Francisco de Souza Mayo: El archivo pasó por varios enlaces de guerra, camuflado con etiquetas de verduras, de bisutería y papelería, para ser llevado a La Junquera el último tramo de tierra Española, colindante con Francia, en Los Pirineos, donde fue enterrado en una tumba, como si se tratase de una baja más en la guerra. Se le colocaron una serie de contraseñas para recuperarlo posteriormente. Y tras su liberación de los campos de concentración franceses: Los Mayo todavia hicieron trámites para que el Partido Comunista desenterrara el tan codiciado archivo de Los Pirineos y lo enviara a Moscú, para su posterior recuperación. Julio Souza (Pascual, 2010) señala: Sé que Dolores Ibárruri, 'Pasionaria', sacó, sin nuestro permiso, una parte de nuestra colección y creo que fue a parar al Museo del Proletario de Moscú. Se llevó las fotos para salvarlas, claro, pero nadie nos dijo nada. Por suerte, hoy podemos encontrar digitalizadas algunas de sus imágenes en la Biblioteca Nacional y en el Archivo fotográfico de la Delegación de Prensa y Propaganda, especialmente aquellas referidas a la Guerra Civil Española, también encontramos fotografías en el Archivo General de la Nación de México y en el Centro Documental de la Memoria Histórica de Salamanca, del Ministerio de Cultura de España (Hernández Ríos y Tolosa Sánchez, 2011)

Tras la muerte en accidente de avión de Francisco en 1949, se une a este grupo de fotógrafos en 1952, Pablo del Castillo Cubillo, hermano de Faustino. Y así en el exilio, como tantos otros españoles, los Hermanos Mayo desarrollaron una prolífica y reconocida carrera fotoperiodística, llegando a ser conocidos en México y unos auténticos desconocidos en su propio país. 


\section{Las fotografías camino del exilio: La maleta mexicana}

Las fotos tomadas por todos estos fotógrafos en la Guerra Civil sirvieron muchas veces como forma de denunciar a la comunidad internacional las atrocidades que se estaban cometiendo sobre la población civil. Estos fotorreporteros españoles convivieron con el pueblo, que fue el único perdedor de esta guerra, al igual que lo hicieron los consagrados fotoperiodistas extranjeros. Si leemos las biografías de Robert Capa, Gerda Taro o David Seymour Chim, veremos que no son fotoperiodistas neutrales sino que toman partido y lo toman por el bando republicano. En palabras de Cornell Capa (hermano de Robert Capa) fueron una brigada internacional de centro-izquierda armada con sus cámaras fotográficas (López Mondejar, 2003:162).

Ello se debe a que la mayoría de estos fotoperiodistas habían huido de su país de origen debido al nazismo y en concreto, a la persecución sistemática emprendida contra los judíos. Por ejemplo, Robert Capa emigró de su Hungría natal a Berlín y desde ahí a París, y lo mismo ocurrió con su compañera Gerda Taro, alemana de nacimiento pero hija de judíos polacos por lo que también emigró a Francia. Ellos ya luchaban antes de la contienda española contra el nazismo y el fascismo en pro de la libertad, por lo que encontraron que los ideales de los republicanos españoles eran también sus ideales, y viajaron hasta España para retratar tanto lo que en el bando republicano acontecía, como el sufrimiento de la población civil. Como medio de publicación de sus fotografías tuvieron amplio eco en las grandes revistas de la época que estaban viviendo en ese momento una auténtica edad de oro. Nos estamos refiriendo a las grandes revistas del fotoperiodismo como: Life en Estados Unidos o Regards, Vu y Ce Soir en Francia.

Pero esta historia ya es de todos conocida, y sólo nos sirve de preámbulo para referirnos al último descubrimiento documental del paradero de un gran número de fotos de los citados míticos fotoperiodistas, que se encontraban en la denominada "Maleta Mexicana", nombre con el se conocen las tres cajas con más de 4.500 negativos recuperados en México DF en el año 2007. Se trata de negativos de fotografías de los tres grandes fotógrafos que estuvieron presentes en la Guerra Civil Española: Robert Capa, Gerda Taro y David Seymour Chim, y que se daban por perdidos. El contenido de esta famosa maleta nos habla precisamente de la importancia de preservar la memoria y, al mismo, tiempo nos resucita toda una época mítica. Lo que ocurrió con aquellos negativos lo podemos resumir así: Robert Capa, al huir de la ocupación Nazi en Francia con rumbo a Nueva York le entrega los negativos a su ayudante Cziki Weisz quién organizó todos los negativos y según él mismo cuenta en 1975: "En 1939, cuando los alemanes se acercaban a París, metí todos los negativos de Bob en una mochila y me la llevé en bicicleta a Burdeos, para intentar embarcarla a México. Por la calle me encontré con un chileno, y le pedí que llevara mis paquetes de pelicula a su consulado, para que no les pasara nada. Accedió" (Young, 2008). Los negativos, en su azaroso destino, llegaron a manos del general Francisco Aguilar González, quien era en aquel momento el embajador mexicano en el gobierno de Vichy en 1941-1942 y quien, supuestamente, los incluyó en su equipaje en su 
regreso a México. Sin embargo, no está claro si el general era consciente o no de la importancia de los negativos y por qué los tuvo tanto tiempo guardados, hasta que su hija Grace, en su lecho de muerte se los confió al director de cine mexicano Ben Tarver, quien a su vez se los entregó, sin ningún tipo de compensación económica, a Cornell Capa, hermano de Robert Capa y conservador de International Center of Photography, donde actualmente se encuentran (Young, 2008).

Estos negativos, entre los que podemos encontrar por ejemplo, la famosa foto de la mujer mirando al cielo mientras amamanta a su bebé, perteneciente a Chim, siguieron el mismo camino que cientos de miles de españoles hacia el exilio, por ello, constituyen uno de los mayores alegatos en contra de la guerra y sus consecuencias, lo que hoy llamamos "daños colaterales" pero que, sin duda, tuvieron entre sus víctimas a personas inocentes. Es por ello, que el valor de los negativos contenidos en la Maleta Mexicana es incontestable. El experto en la Guerra Civil Española, Sebastian Faber, comenta a propósito del documental acerca de esta Maleta, cómo, para una mujer de clase media norteamericana abrir la revista Life y ver fotos de niños rescatados de una casa derrumbada en Madrid o Barcelona por un bombardeo suponía un gran shock (Ziff, 2011). Como vemos, ciertas imágenes suponían un verdadero trauma para el espectador de aquel momento, que recibía las imágenes a través del medio impreso y ya por aquel entonces, con una gran calidad de imagen e impresión.

Sin duda, la fotografía jugó un papel imprescindible documentando la Guerra Civil Española, un papel hasta entonces nunca visto, y así, tres fotoperiodistas extranjeros van a registrar con su cámara un conflicto que sucede fuera de sus países y, sin pretenderlo, crean un nuevo estilo: ya no se fotografía el antes y el después de la batalla, se capta la lucha mientras ocurre: explosiones, fotos borrosas, balas rozando sus cabezas. De este modo, es tal su compromiso y entrega que los tres morirán en distintos conflictos bélicos (Gerda Taro precisamente en España en la batalla de Brunete) como si el titulo del libro de Robert Capa Death in the making fuese una premonición.

\section{Fuentes para el estudio del fotoperiodismo durante la Guerra Civil Española}

\subsection{El Archivo fotográfico de la Delegación de prensa y propaganda de Madrid}

Se trata de un conjunto fotográfico creado por la Junta de Defensa de Madrid en 1936 (aunque encontramos eventos anteriores, como el advenimiento de la II República) como fondo propagandístico para denunciar los desastres de la Guerra Civil. Posteriormente, fue ocultado y utilizado por el bando nacional como instrumento de represión de las ideas políticas. ya que se usaron sus fotografias como testimonio de la oposición al Régimen de muchas de las personas que aparecían inmortalizadas en ellas. Este proceso, además de cambiar el sentido y la función original del Archivo, supuso su disgregación, ya que numerosas imágenes fueron extraídas de él para pasar 
a formar parte de los sumarios de la Causa General. ${ }^{6}$ Con la llegada de la democracia en España, este fondo pasó al Archivo General de la Administración, en Alcalá de Henares. Hoy en día, se encuentra digitalizado y podemos acceder a él a través de Internet.

Este archivo, que contiene 3.051 fotografías, está dividido en veintinueve categorías, que a su vez se subdividen en otras muchas, para conseguir una búsqueda más precisa. Algunas de estas categorías hacen referencia a Armas y material de guerra, Escenas de guerra, Heridos y muertos de guerra, Intendencia o Refugiados. Hay que tener en cuenta que algunas de sus imágenes pueden resultarnos impactantes e incluso muy duras. Este fondo documental cuenta con fotografías de Alfonso, Hermanos Mayo, Antifafot, Aguayo, Albero y Segovia, Baldomero o Lladó, entre otros fotógrafos. Además existe la interesante y valiosa posibilidad de que los visitantes aporten información: desde identificación de personas y lugares, hasta la autoría de dichas imágenes. También dentro del Archivo General de la Administración se encuentra el "Estudio fotográfico Alfonso", donde pueden consultarse todas las fotografías de esta saga de fotógrafos.

4.2. Fondo fotográfico de la Guerra Civil de la Biblioteca Nacional de España (BNE).

La BNE también alberga un importante conjunto fotográfico de la contienda acaecida en España entre 1936 y 1939. Se trata de unas setenta mil imágenes relacionadas con actividades periodísticas y propagandísticas. Todo este material procedía de la Subsecretaría de Educación Popular que, a su vez, fue depositado en la sección de la Guerra Civil creada en 1965 dentro del Ministerio de Información y Turismo. Algunas imágenes, al igual que ocurre con el Archivo fotográfico de la Delegación de Prensa y Propaganda de Madrid, son anteriores al periodo de guerra y hacen referencia a eventos ocurridos durante la II República, y a otros que tuvieron lugar poco después de terminar el conflicto. La temática de las imágenes se divide en numerosas categorías: manifestaciones, edificios bombardeados, batallas y bombardeos, hospitales, retaguardia, etc. Entre los autores de las imágenes podemos encontrar, además de fotógrafos españoles como los que ya hemos visto en este artículo, y otros como: Brangulí, Campúa, Serrano y Foto España; y extranjeros de la talla de Robert Capa, David Seymour Chim y Walter Reuter (Ortega García, 2011:221). También hay imágenes de fotógrafos anónimos y de otros del bando nacional, pero que, como señala Publio López Mondéjar, nunca llegaron a identificarse con las motivaciones de la lucha, tal como lo hicieron los que trabajaron en el campo republicano.

4.3. El Archivo fotográfico de la AABI (Asociación de Amigos de las Brigadas Internacionales)

Durante la Guerra Civil Española unos 35.000 voluntarios de más de 50 países vinieron a combatir a España en defensa de sus ideales y en contra del fascismo, formando parte de unidades integradas en el Ejército de la República, lo que conocemos por las Brigadas Internacionales. Para que su legado histórico no se perdiera 
en junio de 1995 se funda la Asociación de Amigos de las Brigadas Internacionales (AABI), como una asociación pluralista e independiente, sin ánimo de lucro, que tiene entre sus principales funciones la recuperación de la memoria histórica de las BBII: "a través de la reunión, organización y posterior conservación para su consulta de las mayores fuentes posibles tanto escritas como orales, o aquellas otras en distintos soportes que sirvan para conocer el hecho histórico de las Brigadas Internacionales durante la Guerra Civil Española y a sus protagonistas. Asimismo tenía el compromiso de promover todo tipo de actividades culturales encaminadas a mantener viva su memoria y a difundir su historia y su legado de solidaridad internacional en defensa de la libertad". (Pérez, Cela, Calatayud, 2013: 88)

Y entre esa documentación recogida por la $\mathrm{AABI}$ en más de veinte países y también gracias a las donaciones de brigadistas particulares y sus distintas Asociaciones de voluntarios y de amigos, nos encontramos con un importante legado fotográfico, totalmente inédito, que la AABI tiene depositado en el Archivo Histórico Provincial de Albacete. En este artículo solo reseñaremos a modo de ejemplo los legados gráficos más importantes recibidos de particulares y los Archivos en distintos países que albergan fotografías no sólo de las Brigadas Internacionales, sino también de la Guerra Civil Española en general. La mayoría de estas fotografías salieron en su día de España en manos de muchos brigadistas de camino al exilio, algunas se perdieron, otras después de pasar las fronteras de varios países y muchas vicisitudes se encuentran hoy en Archivos no sólo de Moscú -como muchos investigadores conocen- sino también -y hoy todavía desconocido por los investigadores- de Praga o Varsovia. Y no digamos todas aquellas fotografías que se quedaron en los archivos particulares de los propios brigadistas. Aquí solo ofreceremos algunas de estas fuentes documentales, las principales, y de una forma poco exhaustiva, pues hacerlo de forma más pormenorizada sería el objeto de estudio de otro artículo.

Queremos reseñar en lo que respecta a fotografías de legados privados el de: Cedo Kapor, veterano de la antigua Yugoslavia, y que ofrece interés por la situación de guerra reciente que ha vivido su país; el de François Mazou que fue comisario político de la XIV Brigada, y que nos aporta documentación gráfica de los brigadistas franceses; el de la familia de Hans Baimler que nos muestra la situación de los brigadistas judíos de Austria; el de Mihail Florescu, ministro del Gobierno rumano durante un largo período de su historia, y que nos da cuenta de los rumanos que estuvieron en España y su paso por los campos de concentración y la resistencia francesa. Y son muchos los legados personales fotográficos que están hoy depositados en Albacete, -ciudad que fue en su día la sede de las BBII-, de voluntarios: chinos, ingleses, canadienses, polacos, austríacos, alemanes, norteamericanos, argentinos, irlandeses, holandeses, etc. Pero no queremos dejar en el olvido dos legados importantes: el del brigadista polaco Michal Bron que donó 61 fotografías de gran calidad del frente y la vida en las trincheras de los brigadistas polacos, un contingente muy importante de voluntarios en la Guerra Civil. Y el Archivo fotográfico del General Walter, el más importante que se haya conservado en manos privadas y que recibió la AABI en 1997, gracias a la donación realizada por las hijas del propio General, quienes 
lo habían conservado hasta entonces. Un fondo documental que consta de 332 fotografías inéditas de la Guerra Civil Española, que sirvió de base para la exposición inaugurada en septiembre de 2005 en el Cuartel de Conde-Duque de Madrid, bajo el título: El Archivo personal del General Walter.

$\mathrm{Y}$ aunque sea brevemente no queremos dejar de reseñar los Archivos que conservan las mejores fuentes documentales gráficas no sólo de las Brigadas Internacionales, sino también de la Guerra Civil Española. De entre los que vamos a dar cuenta en este artículo (la mayoría visitados por las autoras de este trabajo) veremos Archivos conocidos por los historiadores, pero otros todavía son prácticamente desconocidos. Además del Archivo Estatal Ruso de Historia Contemporánea (RGASPI) ya visitado por muchos investigadores, nos encontramos con otros Archivos situados en lo que fue la Europa del Este que albergan importantes fuentes documentales gráficas que son prácticamente desconocidas, nos referimos por ejemplo al Archivo de Actos Nuevos de Varsovia, donde nos encontramos más de 3.000 fotografías inéditas de la Guerra Civil Española, perfectamente catalogadas y conservadas (aunque todavía de forma rudimentaria), que nos dan cuenta no sólo de los brigadistas polacos, sino también de los distintos frenes de batalla, de las trincheras, de la vida cotidiana en la guerra y en los campos de concentración de Francia y el norte de Argelia. Otros Archivos importantes y prácticamente desconocidos que albergan un importante legado documental -aunque no tengan el volumen del Archivo polaco- son: El Archivo Nacional de Hungría, situado en Budapest que posee un archivo con diversos tipos de documentos de los brigadistas húngaros, así como un apartado fotográfico específico de los combatientes húngaros en la Guerra Civil Española. El Instituto de Estudios Históricos y la Biblioteca de la Academia Rumana, de Bucarest, que también cuenta con un archivo fotográfico en fichas documentales de todos los combatientes rumanos. También destacaríamos la importancia del Archivo Nacional de Bulgaria, en Sofia, con un significativo corpus fotográfico correspondiente a los servicios sanitarios en la Guerra Civil, dada la importancia de la colaboración de los médicos y enfermeras búlgaros, que incluye instantáneas de hospitales, como el de Benicassim. El Archivo Español del Centro de Documentación de la Resistencia Austriaca, en Viena, que incluye un archivo fotográfico de todos los brigadistas austriacos, alemanes y fotografías de los campos de batalla y la retaguardia; al igual que el Archivo de Historia Militar, en Praga, con respecto a los brigadistas checos. Además existen otros importantes Archivos mucho más conocidos en los que nos hemos encontrado un importante legado fotográfico tales como: el Imperial War Museum y Marx Memorial Library en Londres, en este último todavía se encuentra pendiente de clasificación y digitalización la gran mayoría de las fotografías correspondientes a la Guerra Civil. Y además este Archivo custodia el legado sindicalista británico, en el que su máximo representante fue el brigadista Jack Jones, del que no sólo hay fotografías en la Guerra Civil con otros brigadistas británicos sino también de toda su trayectoria en los movimientos sindicales de su país. Otro archivo fotográfico a reseñar es el de la Biblioteca Tamiment de la Universidad de Nueva York, que reúne las fotografías de los veteranos de la Brigada Abraham Lincoln. 


\section{Conclusiones}

En este artículo hemos querido exponer la importancia que tienen las fuentes documentales gráficas para el estudio de la historia, en este caso las fuentes documentales que se conservan de un período fundamental de nuestra historia contemporánea, la Guerra Civil Española. Gracias a la investigación en archivos de distintos países (pues no sólo los españoles se vieron involucrados en la contienda), y a los legados conservados por muchos ciudadanos anónimos se ha podido reunir una gran documentación gráfica, de la que podemos denominar la guerra fotografiada por excelencia. Hasta entonces ningún otro conflicto bélico había sido fotografiado de la misma forma a lo que contribuyó: el interés de un público ávido de imágenes, la proliferación de las revistas gráficas, las nuevas cámaras y técnicas fotográficas, y lo más importante, los fotoperiodistas que lo hicieron posible.

A la Guerra Civil Española acudieron fotoperiodistas de casi todos los países del mundo para dar cuenta a sus periódicos y revistas de un acontecimiento de interés mundial, de entre estos fotoperiodistas extranjeros destacaron tres que forjaron en España su propia leyenda: Robert Capa, Gerda Taro y David Seymour Chim. Su trabajo fue ejemplo del mejor y más avanzado fotoperiodismo, pero ellos no fueron los únicos, también existían un buen número de fotoperiodistas españoles que inmortalizaron la Guerra Civil Española, con la misma calidad de imágenes y utilizando técnicas tan avanzadas, además de verse mucho más implicados en el conflicto bélico, ya que el escenario que retrataban era el de su propio país, su propia casa, y a sus compatriotas. Desgraciadamente estos fotoperiodistas españoles no forjaron leyenda y su gran trabajo fue condenado al olvido, debido al silencio que impuso la dictadura franquista. Una vez llegada la democracia a nuestro país sus fotografías han ido apareciendo en libros y exposiciones reivindicativas de su memoria. Y así, gracias a la difusión que se está realizando en estos últimos años para darlos a conocer, hemos podido rescatar del olvido el trabajo fotoperiodístico de Agustí Centelles, Alfonso o el colectivo de fotógrafos que fueron los Hermanos Mayo.

También queremos destacar en las conclusiones a las que hemos llegado con la investigación de este artículo, un aspecto que nos ha llamado la atención, la coincidencia espacio temporal de algunos de los fotoperiodistas aquí reseñados. Cómo Agustí Centelles coincide con Robert Capa en los mismos escenarios bélicos, e incluso realizando fotografías muy similares de la contienda. La coincidencia también en los campos de concentración franceses en los que estuvieron internados los Hermanos Mayo y que inmortalizaron con sus fotografías, y que también fueron visitados por Robert Capa que tomó también instantáneas de los mismos. Y cuando los Hermanos Mayo consiguen salir de los campos de concentración del sur de Francia y encaminarse al exilio mexicano, estos embarcan en el puerto de Sète, en un barco que había puesto el Gobierno mexicano a disposición de los expatriados españoles, el mítico Sinaía que partía rumbo a Veracruz, y en ese mismo barco también se encontraba la Maleta Mexicana, que viajaba hacia el exilio, sin saber que en ella se hallaban las 
fotografías que forjaron la leyenda de otro de los pasajeros que viajaban en el barco, David Seymour Chim, quién a su vez también fue fotoperiodista en España ${ }^{7}$.

\section{Referencias bibliográficas}

BECEYRO, Raúl (2003): Ensayos sobre fotografia. Buenos Aires: Paidós. BERGER, John (2013): Understanding a photograph. Nueva York: Aperture. CAPA Robert (1938): Death in the making. Nueva York: Covici-Friede Publishers. CENTELLES, Agustí (2006): Las vidas de un fotógrafo. Barcelona: Lunwerg Editores.

COSTA, Joan (1977): El lenguaje fotográfico. Madrid: Ibérico Europea de Ediciones. EMERLING, Jae (2012): Photography. History and theory. Nueva York: Routledge. EMERY HULICK, Diana y MARSHALL, Joseph (1998): Photography, 1900 to the present. New Jersey: Prentice Hall.

ELVIRA, Paco (2011): La Guerra Civil Española. Imágenes para la historia. Barcelona: Lunwerg.

FREUND, Gisèle (2002): La fotografía como documento social. Barcelona: Gustavo Gili.

GUERRA DE LA VEGA, Ramón (2005): Historia de la fotografía. Tomo 2: II República y Guerra Civil (1931-1939). Madrid: Street Art Collection.

JOHNSON, William S.; RICE, Mark y WILLIAMS Carla (2012): The George Eastman House Collection: Historia de la fotografia: de 1839 a la actualidad. Colonia: TASCHEN.

KERSHAW, Alex (2010): Sangre y champán: la vida y época de Robert Capa. Barcelona: Debolsillo.

LEDO, Margarita (1998): Documentalismo fotográfico: Éxodos e identidad. Madrid: Cátedra.

LEFEBVRE-PEÑA, Michel (2013): Guerra gráfica. Fotógrafos, artistas y escritores en guerra. España 1936-1939. Barcelona: Lunwerg.

LÓPEZ MONDEJAR, Publio (2013): Historia de la fotografia en España. Madrid: Lunwerg Editores.

MASPERO, François (2010): Gerda Taro, la sombra de una fotógrafa. Madrid: La Fábrica.

MORENO, Rafael y BAULUZ, Alfonso (2012): Fotoperiodistas de guerra españoles. Madrid: Turner.

NEWHALL, Beaumont (2002): Historia de la Fotografia. Barcelona: Gustavo Gili.

OLMEDA, Fernando (2007): Gerda Taro, fotógrafa de guerra: el periodismo como testigo de la historia. Barcelona: Debate.

ORTEGA GARCÍA, Isabel (2011): Selección del fondo fotográfico de la Guerra Civil Española en La fotografía en la BNE. Madrid: BNE.

PONIATOWSKA, Elena (2011): Leonora. Barcelona: Seix Barral.

PRESTON, Paul (2007): Idealistas bajo las balas. Corresponsales extranjeros en la guerra de España. Barcelona: Debate 
SÁNCHEZ VIGIL, Juan Miguel (2001): Alfonso: Imágenes de un siglo. Madrid: Espasa Calpe.

SÁNCHEZ VIGIL, Juan Miguel y OLIVERA ZALDUA, María (2013): Fotoperiodismo República : Prensa y reporteros gráficos, 1931-1939. Madrid: Cátedra.

SOUGEZ, Marie Loup (coord.) (2007): Historia General de la Fotografia Madrid: Cátedra.

SOUSA, Jorge Pedro (2003): Historia del fotoperiodismo occidental. Sevilla: Comunicación Social.

V.V.A.A (2010): Héroes sin armas. Fotógrafos españoles en la Guerra Civil. El frente de Madrid. Madrid: Sociedad estatal de conmemoraciones culturales.

V.V.A.A. (1998): Voluntarios de la libertad. Las Brigadas Internacionales. Catálogo de la exposición. Madrid: Asociación de Amigos de las Brigadas Internacionales (AABI)ñoles en la Guerra Civl rublicano.vaciones de la lucha,ia a algunos eventos ocurridos durante la II Rep

YOUNG, Cynthia (ed.) (2011): La maleta mexicana : las fotografías redescubiertas de la Guerra Civil Española de Capa, Chim y Taro. Madrid: La Fábrica, Fundación Pablo Iglesias.

WHELAN, Richard (2009): ¡Esto es la guerra! Robert Capa en acción. Barcelona: Museu Nacional d'Art de Catalunya.

Revistas científico-profesionales

CUSTODIO, Álvaro (1977): Alfonso, fotógrafo de la historia en: Tiempo de historia. Madrid: Prensa Periódica S.A. Págs. 20-41

FERRÉ PANISELLO, Teresa (2012): L'arxiu Centelles: història d'una maleta i el seu contingut en Comunicació: Revista de Recerca i d'Anàlisi (Societat Catalana de Comunicació). Vol.29.

HERNÁNDEZ RÍOS, María Luisa y TOLOSA SÁNCHEZ, Guadalupe (2011): La imagen fotográfica como documento de lo perdurable: el discurso visual de las instantáneas de los Hermanos Mayo en Discurso Visual: Cenidiap. Número 18. Disponible en línea: http://discursovisual.net/dvweb18/agora/agoriostolosa.htm [Fecha de consulta el 21 de mayo de 2014]

MRAZ, John (2000): Los Hermanos Mayo. Photographing exile. Film-Historia, Vol. X, No.1-2 7-27. Disponible en línea: http://www.publicacions.ub.edu/bibliotecaDigital/cinema/filmhistoria/Art.Mraz2.pdf [Fecha de consulta el 21 de mayo de 2014]

PÉREZ, Ana, CELA, Julia R. y CALATAYUD, Gemma (2013): La memoria de las Brigadas Internacionales a través de la Documentación recogida por la Asociación de Amigos de las Brigadas Internacionales (AABI): Documentación de las Ciencias de la Información. Vol. 36.

Webgrafía

CENTRO DE LA IMAGEN (2010): La ruta del Sinaia documentada por Chim [en línea] http://centrodelaimagen.wordpress.com/2011/02/03/la-ruta-del-sinaia-documentada-por-chim/ [fecha de consulta: 21 de mayo de 2014] 
DE SOUZA MAYO, Francisco (N.D): Los Hermanos Mayo. Francisco, Cándido, Julio, Faustino y Pablo. Ni todos eran hermanos, ni todos eran Mayo [en línea]. http://www.hermanosmayo.com/images/vinculo/hnosmayo.pdf [fecha de consulta: 21 de mayo de 2014]

EFE: Capa y Centelles: fotógrafo rico fotógrafo pobre en La Razón Digital [en línea] 21/05/2012 http://www.larazon.es/detalle_hemeroteca/noticias/LA_RAZON_459190/2890-capa-y-centelles-fotografo-rico-fotografo-pobre\#Ttt1uNLhZqolGZof [fecha de consulta: 21 de mayo de 2014]

OLIVA, José y MARIÑOSA, Héctor: Hallan fotos inéditas de Centelles donde aparece Capa tras Azaña y Negrín en La información.com [en línea] 19/05/2012 http://noticias.lainformacion.com/arte-cultura-y-espectaculos/historia/hallan-fotos-ineditas-de-centelles-donde-aparece-capa-tras-azana-y-negrin_uaPwPgnsTsn9pD6VqfnKD6/ [Fecha de consulta el 21 de mayo de 2014]

YOUNG, Cynthia (2008): Historia de la Maleta Mexicana [en línea]. http://museum. icp.org/mexican_suitcase/castella/historia.html [Fecha de consulta: 15 de abril de 2013]

TRALLERO, Manuel: La famosa foto de los caballos estaba preparada. El mundo.es [en línea] 29/12/2009 http://www.elmundo.es/elmundo/2009/12/28/ cultura/1262025047.html fecha de consulta 21 de mayo de 2014]

EL PAÍS (1984): El fotógrafo Centelles, los pintores Caballero, Mompó y Genovés, y el escultor Lobo, premios nacionales de Artes Plásticas, [en línea] 30/11/1984, http://elpais.com/diario/1984/11/30/cultura/470617204_850215.html [consultado el 8 de mayo de 2014]

PORTAL DE ARCHIVOS ESPAÑOLES: Historia del Archivo Fotográfico de la Delegación de Prensa y Propaganda de Madrid. Ministerio de Educación, Cultura y Deporte [en línea] http://pares.mcu.es/ArchFotograficoDelegacionPropaganda/ inicio.do [consultado el 15 de abril de 2014]

Videos

ZIFF Trisha (2011): La maleta mexicana [video] México-España: 212 Berlin \& Mallerich Films Paco Poch, (52:09 min.).

\section{Notas}

1 Véase punto 2.3 del presente artículo.

2 En cuanto a ANTIFAFOT se da un hecho curioso, y es que no queda claro si se trató de un colectivo de fotógrafos, una agencia o un laboratorio fotográfico, ni quiénes fueron sus integrantes. Paco Elvira en su libro La Guerra Civil Española. Imágenes para la historia (citado en este artículo) señala que se trataba de una agencia a través de la cual otros fotógrafos distribuían sus imágenes. Evelia Rojo, jefa del departamento de referencias del Archivo General de la Administración, señala, (en contestación a un email del 7 de abril de 2014, enviado por las autoras de este artículo): Al parecer ANTIFAFOT, era un colectivo de fotógrafos del Partido Comunista y funcionaba como un laboratorio fotográfico 
Oficial. Según Beatriz de las Heras Herrero, en la página 151 de su artículo Madrid y Burgos, 19361939: representación visual de las mujeres a través del fondo fotográfico de la guerra civil en la Biblioteca Nacional, ANTIFAFOT es laboratorio y agencia fotográfica del Partido Comunista Y en el diario Público se dice que ANTIFAFOT era en realidad un colectivo del PCE que buscaba las imágenes más crudas para remover las conciencias (véase PÚBLICO.ES: El Archivo Rojo en Internet [en línea] (2008) http://www.publico.es/127457/el-archivo-rojo-en-internet [consultado el 19 de mayo de 2014].

3 Julio no se unió a ellos en el exilio mexicano hasta 1947 debido a que fue hecho prisionero por soldados italianos en Alicante. Después estuvo en la cárcel y más tarde trabajó como fotógrafo de espectáculos. Tras casarse solicitó un visado para irse de luna de miel a Nueva York que aprovechó para escapar y reunirse en México con sus hermanos.

4 Tal y como cuenta Francisco de Souza Mayo, Cándido Souza desarrolló desde el principio un método para el ordenamiento del archivo y la recuperación de negativos por tema o cronológicamente que sería adoptado por los periódicos de la ciudad de México y después por los de provincia.

5 Si echamos un vistazo a la página web de uno de los hijos de los Hermanos Mayo podemos encontrar información acerca del trasvase de fondos desde el Archivo General de la Nación de México al Archivo Histórico Nacional, Sección Guerra Civil, el 30 de junio de 1992 hoy Archivo General de la Guerra Civil Española integrado en el Centro Documental de la Memoria Histórica de Salamanca. Se trata de un conjunto de 3.861 imágenes, casi todas documentan el exilio español en México entre 1939 y 1977, sin embargo hay algunas anteriores al exilio. En la misma web se encuentra el contrato de compraventa entre Julio Souza y el Archivo General de la Nación de México firmado en 1982, y por el cual el primero vende por once millones de pesos mexicanos un total de 5 millones de negativos al AGNM. Véase DE SOUZA MAYO: Hermanos Mayo [en línea] http://www.hermanosmayo.com/ hnosmayo.html [consultado el 1 de junio de 2014]

6 PORTAL DE ARCHIVOS ESPAÑOLES: Historia del Archivo Fotográfico de la Delegación de Prensa y Propaganda de Madrid. Ministerio de Educación, Cultura y Deporte [en línea] http://pares. mcu.es/ArchFotograficoDelegacionPropaganda/inicio.do [consultado el 15 de abril de 2014]

7 En cuanto a la posible duda de si llegaron a conocerse o entablar conversación los Hermanos Mayo con David Seymour Chim mientras viajaban en el Sinaía rumbo a México, el hijo de Cándido, uno de los integrantes de los Hermanos Mayo, señala en un email a las autoras con fecha del 23 de junio de 2014: Se que tenían contacto en México pues Chim era un fotógrafo judio muy importante en esos tiempos y se que tenían relación amistosa con mi padre Cándido y con mis tíos Paco y Faustino. Que son los únicos Mayo que lo conocieron. Siempre en conversaciones salía a relucir el experimentado fotógrafo polaco. Sobre todo porque según recuerdo él hablaba varios idiomas y era experto en cámaras de formato grande y les pedía consejos a los Hermanos Mayo por las cámaras de 35mm. de marca Leica modelo R3 y más, sobre el uso de telefotos y el manejo de filtros que Paco y Cándido eran expertos. Pero no recuerdo por conversaciones con mi padre que él hubiere estado en el buque francés Sinaía, pues sin duda yo lo recordaría.

\section{Las autoras}

Julia Rodríguez Cela es profesora de Documentación, Telemática y Técnicas Documentales en el Master de Periodismo y Educación de la Universidad Complutense de Madrid, 1987-1991. Es profesora contratado Doctor en el Departamento de Biblioteconomía y Documentación de la Facultad de Ciencias de la Informa- 
ción, UCM, desde octubre de 2006. Directora de Investigación: Archivo y edición de la obra inédita de Juan Marichal, financiado por la Presidencia del Gobierno de Canarias, 2003. Investigadora: Centro Virtual Cervantes, financiado por el Instituto Cervantes, 2004-en curso.

Alicia Parras Parras es Investigadora del Departamento de Biblioteconomía y Documentación, Facultad de Ciencias de la Información. 